\title{
Changes in the physical properties, solubility, and heat stability of milk protein concentrates prepared from partially acidified milk
}

\author{
H. Eshpari, ${ }^{\dagger} \dagger$ P. S. Tong, $\dagger$ and M. Corredig ${ }^{* 1}$ \\ *Department of Food Science, University of Guelph, Guelph, Ontario N1G 2W1, Canada \\ †Dairy Products Technology Center, California Polytechnic State University, San Luis Obispo 93407
}

\begin{abstract}
A limiting factor in using milk protein concentrates (MPC) as a high-quality protein source for different food applications is their poor reconstitutability. Solubilization of colloidal calcium phosphate (CCP) from casein micelles during membrane filtration (e.g., through acidification) may affect the structural organization of these protein particles and consequently the rehydration and functional properties of the resulting MPC powder. The main objective of this study was to investigate the effects of acidification of milk by glucono- $\delta$-lactone (GDL) before ultrafiltration (UF) on the composition, physical properties, solubility, and thermal stability (after reconstitution) of MPC powders. The MPC samples were manufactured in duplicate, either by UF (65\% protein, MPC65) or by UF followed by diafiltration ( $80 \%$ protein, MPC 80$)$, using pasteurized skim milk, at either the native milk $\mathrm{pH}$ $(\sim \mathrm{pH} 6.6)$ or at $\mathrm{pH} 6.0$ after addition of GDL, followed by spray drying. Samples of different treatments were reconstituted at 5\% (wt/wt) protein to compare their solubility and thermal stability. Powders were tested in duplicate for basic composition, calcium content, reconstitutability, particle size, particle density, and microstructure. Acidification of milk did not have any significant effect on the proximate composition, particle size, particle density, or surface morphology of the MPC powders; however, the total calcium content of MPC80 decreased significantly with acidification (from $1.84 \pm 0.03$ to $1.59 \pm 0.03 \mathrm{~g} / 100 \mathrm{~g}$ of powder). Calcium-depleted MPC80 powders were also more soluble than the control powders. Diafiltered dispersions were significantly less heat stable $\left(\right.$ at $\left.120^{\circ} \mathrm{C}\right)$ than UF samples when dissolved at 5\% solids. The present work contributes to a better understanding of the differences in MPC commonly observed during processing.
\end{abstract}

Key words: milk protein concentrate, partial acidification, physical properties, solubility, heat stability

Received July 12, 2014.

Accepted September 12, 2014.

${ }^{1}$ Corresponding author: milena.corredig@uoguelph.ca

\section{INTRODUCTION}

Milk protein concentrate (MPC) powders are manufactured from skim milk by membrane filtration and spray drying. The major components of these shelfstable food ingredients are protein, lactose, fat, and minerals. The proportion of these components varies depending on the extent of concentration and the type of membrane separation used. The proteins in MPC consist of caseins and whey proteins, present at the same ratio (4:1) as in milk.

Milk protein concentrate powders may present poor solubility (Mistry and Pulgar, 1996; McKenna, 2000; Anema et al., 2006; Havea, 2006; Baldwin and Truong, 2007; Mimouni et al., 2010; Sikand et al., 2011). Poor solubility has been attributed to the slow release of casein micelles from powder particles; it is shown that the slowly solubilizing material is almost entirely made up of caseins, whereas the whey proteins, minerals, and lactose are more soluble (Anema et al., 2006; Havea, 2006; Mimouni et al., 2010). It is widely believed that the processes involved in manufacture of MPC maintain the overall original state of casein micelles (Mulvihill and Ennis, 2003). The delicate ionic equilibrium between serum and micelles in milk (Holt et al., 1981) is shifted during membrane filtration. This change may cause a lasting effect on the casein micelles, affecting their rehydration and the functional properties of the resulting concentrates. It is known that certain processing steps can improve the rehydration properties of MPC powders; for example, heating the milk after $\mathrm{pH}$ adjustment before membrane filtration (Blazey et al., 2000), drying at lower temperatures (Schuck et al., 1994), adding salts before or after UF (Carr, 2002; Schuck et al., 1999, 2002; Mao et al., 2012; Sikand et al., 2013), adding sodium caseinate to the retentate before spray-drying (Schokker et al., 2011), adding polydextrose and whey proteins (Davenel et al., 1997), or partly depleting calcium by adding chelating agents, using cation exchange chromatography, or acidifying the milk (Bhaskar et al., 2001).

Little has been written about the effect of partial acidification of milk before UF on the composition, physical properties, and rehydration behavior of the re- 
sulting MPC powders. Investigating the effects of such manipulations on the thermal stability of the resulting powders after reconstitution is also of considerable interest, as these ingredients are often subjected to extensive heat treatments when incorporated into beverages. In such applications, the ability to withstand heating regimens as high as, for example, $121^{\circ} \mathrm{C}$ for $15 \mathrm{~min}$, is very important.

In this study, we explored the effect of acidification to $\mathrm{pH} 6$ by addition of glucono- $\delta$-lactone (GDL), on the physical properties, reconstitutability, and thermal stability (after reconstitution). Milk pH was modified before ultrafiltration, which was then carried out with or without a subsequent diafiltration (DF) stage. This work attempted to use methods for reconstitution and observations commonly used in the industry to depict the properties of the powders under conditions relevant to processors.

\section{MATERIALS AND METHODS}

\section{Materials}

Pasteurized skim milk was obtained from Producer's Dairy Foods Inc. (Fresno, CA). Analytical-grade reagents were from Sigma-Aldrich Chemical Co. (St. Louis, MO). Glucono- $\delta$-lactone was purchased from Roquette America Inc. (Geneva, IL). When added to an aqueous solution, GDL dissolves rapidly but hydrolyses progressively to gluconic acid, leading to a controlled decrease of $\mathrm{pH}$, which suited the purposes of this research. Ultrapure water (Milli-Q Ultrapure Water Purification Systems, Billerica, MA) was used to prepare all the solutions.

\section{Preparation of MPC Powders Acidified with GDL}

Milk protein concentrate powders were manufactured in duplicate using pasteurized skim milk, either by UF to achieve an MPC with $65 \%$ protein (MPC65) or by UF followed by DF to achieve an MPC with $80 \%$ protein (MPC80). Controls were prepared at the native milk $\mathrm{pH}(\sim \mathrm{pH} 6.6)$ or GDL was added (at $3.25 \mathrm{~g} / \mathrm{L}$ ) to reach $\mathrm{pH} 6.0$ before starting membrane filtration; GDL gradually decreases the $\mathrm{pH}$ of milk and is often used as a model for lactic acid fermentation in milk. The $\mathrm{pH}$ value of 6.0 was selected because little physical and chemical changes occur to the casein micelles at this $\mathrm{pH}$ (Alexander and Dalgleish, 2004). By doing so, the effect of limited acidification could be studied. Figure 1 illustrates the various stages of MPC manufacture. The MPC65 and MPC80 powders were manufactured in the pilot plant of Dairy Products Technology Center at California Polytechnic State University (San Luis
Obispo). Pasteurized skim milk (300 kg) was ultrafiltered by using a model R12 cross-flow membrane recirculatory pilot plant unit (Niro Inc., Hudson, WI) equipped with dual 10-kDa-cut-off, spiral-wound polyethersulfone membranes (Snyder Filtration, Vacaville, CA). Ultrafiltration began at $5.8^{\circ} \mathrm{C} \pm 1.5^{\circ} \mathrm{C}$. During $\mathrm{UF}$, the temperature was allowed to increase in such a way that by the end of the UF process, the temperature was $20 \pm 1.6^{\circ} \mathrm{C}$. Milk was concentrated up to $5 \times$ concentration, resulting in $60 \mathrm{~kg}$ of retentate. The UF retentate was then divided into 2 equal portions, $30 \mathrm{~kg}$ of which was spray-dried and the other $30 \mathrm{~kg}$ was diafiltered to achieve $6 \times$ concentration using the same membrane pilot-plant unit, mentioned above. At the end of DF, $20 \mathrm{~kg}$ of retentate was collected and spray-dried. Both UF and DF retentates were spraydried with a pilot Niro Filtermat Spray Dryer (Niro Inc.) to approximately $3.5 \%$ moisture, and the obtained MPC powders were immediately collected and sealed in airtight bags for further analysis. Inlet temperature was about $210^{\circ} \mathrm{C}$ and outlet temperature was $82^{\circ} \mathrm{C}$. Four MPC powders were produced (Figure 1), 2 MPC65 and 2 MPC80. The control samples were named UF-C and DF-C and the GDL-treated samples were named UF-G and DF-G.

\section{Composition}

Powder samples were analyzed for proximate composition (AOAC International, 1995). Total protein was determined by Kjeldahl. Ash content was determined by ignition at $550^{\circ} \mathrm{C}$ in an electric muffle furnace (AOAC International, 1995; method 945.46; 33.2.10). Fat content was determined by the Mojonnier method (AOAC International, 1995; method 989.05; 33.2.26), and free moisture content by oven-drying method (AOAC International, 1995; method 990.20; 33.2.44). Lactose was determined by difference.

Total Ca content of the powders was determined by using Hewlett Packard 4500 ICP-MS (Agilent Technologies, Santa Clara, CA), according to EPA method 6020 A (US EPA, 2007).

\section{Solubility Determination}

The MPC powders were reconstituted in ultrapure water $(5 \% \mathrm{wt} / \mathrm{wt})$ for $3 \mathrm{~h}$ using a laboratory stage mixer (R010 Power, IKA Works, Wilmington, NC) at $960 \mathrm{rpm}$ (speed setting \#8) at $23^{\circ} \mathrm{C} \pm 1.0^{\circ} \mathrm{C}$. Aliquots $(13 \mathrm{~mL})$ of these samples were transferred to a series of 15 -mL Falcon tubes and centrifuged at $700 \times g$ for $10 \mathrm{~min}$ at $23^{\circ} \mathrm{C}$. The supernatant was separated from the pelleted material by withdrawing the supernatant into a pipette. Total solids (TS) contents of both bulk 


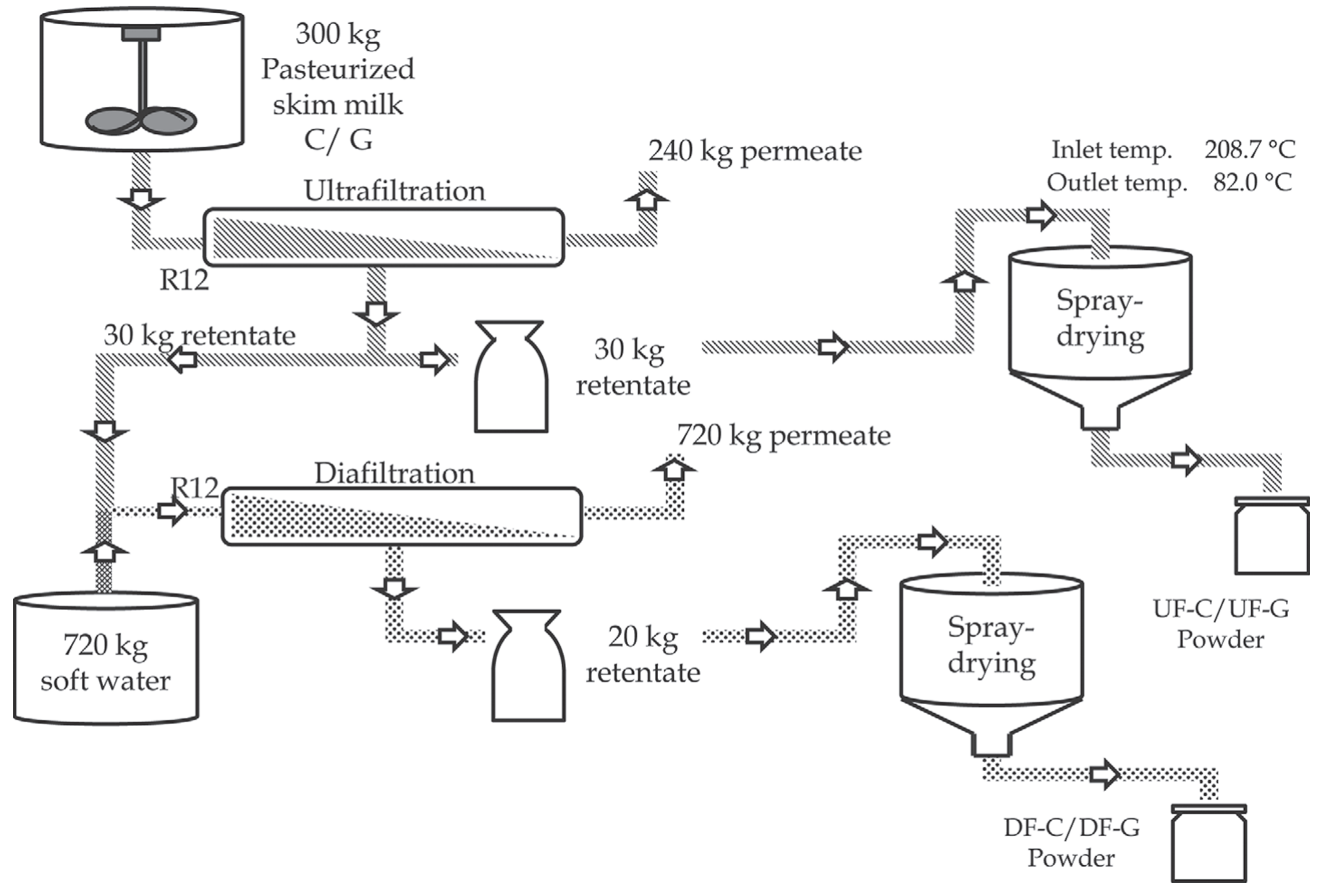

Figure 1. Flow diagram of the manufacture of pilot plant powders. UF-C $=$ UF control; UF-G $=$ UF and acidified with glucono- $\delta$-lactone $(\mathrm{GDL}) ; \mathrm{DF}-\mathrm{C}=$ diafiltered control; DF-G = diafiltered and acidified with GDL.

MPC solution and the supernatants were determined using CEM LabWave 9000 microwave (CEM Corp., Matthews, NC). Solubility was calculated according to the following equation:

$$
\text { Solubility }(\%)=\frac{\text { TS in supernatant }(\%)}{\text { TS in bulk MPC solutions (\%) }} \times 100 \text {. }
$$

\section{Particle Density Analysis}

The particle density of the MPC powders was measured by using an Accupyc 1340 gas pycnometer (Micromeritics, Norcross, GA) according to the air pycnometer method of GEA Niro (2006; GEA Niro method A.11.a).

\section{Particle Size Distribution Analysis of Reconstituted MPC Powders}

Particle size distribution of the MPC samples (reconstituted as described above) was determined by inte- grated light scattering (Mastersizer 2000, Malvern Instruments, Southborough, MA). The volume-weighted mean particle diameter $\left(\mathrm{d}_{4,3}\right)$ was recorded. A few drops of reconstituted MPC dispersions were added into the small-dispersion unit to reach an obscuration level of 10 to 20 (dilution factor in water was approximately $10^{-3}$ ) while stirring at $2,800 \mathrm{rpm}$. The refractive indices used in particle size distribution calculations were 1.39 for the casein micelles (Alexander et al., 2002) and 1.33 for water.

\section{Surface Morphology}

Scanning electron microscopy was performed on powder samples mounted on aluminum stubs with double-sided adhesive carbon tape. The powder was lightly dusted over the tape and excess particles were removed by gently shaking the stub. Samples were then coated with gold-palladium alloy in a Desk V HP series sputter coater (Denton Vacuum LLC, Moorestown, $\mathrm{NJ}$ ) for $3 \mathrm{~min}$ to give a coating of around $10 \mathrm{~nm}$. The 
Table 1. Composition (mean $\pm \mathrm{SD}$ ) of milk protein concentrate powders ${ }^{1}$

\begin{tabular}{|c|c|c|c|c|c|c|c|}
\hline \multirow[b]{2}{*}{ Powder $^{2}$} & \multicolumn{6}{|c|}{ Component $^{3}$ (g 100/g of powder) } & \multirow[b]{2}{*}{$\mathrm{pH}$} \\
\hline & Total protein & Fat & Lactose & Ash & Moisture & Total Ca & \\
\hline UF-C & $65.45 \pm 0.5^{\mathrm{a}}$ & $2.38 \pm 0.02^{\mathrm{a}}$ & $19.5^{\mathrm{a}}$ & $8.1 \pm 0.2^{\mathrm{a}}$ & $3.5 \pm 0.1^{\mathrm{a}}$ & $1.43 \pm 0.03^{\mathrm{a}}$ & $6.95 \pm 0.01^{\mathrm{a}}$ \\
\hline UF-G & $65.13 \pm 0.9^{\mathrm{a}}$ & $2.77 \pm 0.10^{\mathrm{ab}}$ & $20.3^{\mathrm{a}}$ & $8.3 \pm 0.2^{\mathrm{a}}$ & $3.6 \pm 0.3^{\mathrm{a}}$ & $1.38 \pm 0.07^{\mathrm{a}}$ & $6.52 \pm 0.01^{\mathrm{b}}$ \\
\hline DF-C & $80.52 \pm 0.6^{\mathrm{b}}$ & $2.41 \pm 0.01^{\mathrm{b}}$ & $5.2^{\mathrm{b}}$ & $7.8 \pm 0.1^{\mathrm{a}}$ & $4.1 \pm 0.3^{\mathrm{a}}$ & $1.84 \pm 0.03^{\mathrm{b}}$ & $7.11 \pm 0.02^{\mathrm{c}}$ \\
\hline DF-G & $81.09 \pm 1.0^{\mathrm{b}}$ & $2.52 \pm 0.03^{\mathrm{b}}$ & $4.8^{\mathrm{b}}$ & $8.2 \pm 0.3^{\mathrm{a}}$ & $3.5 \pm 0.1^{\mathrm{a}}$ & $1.59 \pm 0.03^{\mathrm{c}}$ & $6.60 \pm 0.01^{\mathrm{d}}$ \\
\hline
\end{tabular}

samples were examined with a FEI Quanta 200 scanning electron microscope (FEI Company, Hillsboro, OR) operated at spot size of 4.5 , accelerating voltage of $10 \mathrm{kV}$, and a working distance of 6 to $12 \mathrm{~mm}$. Sample preparation and imaging were conducted in duplicate.

\section{Heat Coagulation Time}

The heat coagulation time (HCT) of the MPC solutions ( $5 \% \mathrm{wt} / \mathrm{wt}$ on solids) was determined following the method described by Davies and White (1959) with some modifications: a 3 -mL aliquot of each solution was transferred to a heat-resistant screw-cap test tube (internal diameter $10 \mathrm{~mm}$, length $100 \mathrm{~mm}$ ). The test tubes were fixed to a metal platform and immersed in an oil bath maintained at $120^{\circ} \mathrm{C}$. The $\mathrm{HCT}$ was recorded as the time elapsed between immersing the samples in the hot oil bath and the onset of visible clots. The HCT of the solutions was tested both before $\mathrm{pH}$ adjustment and after adjusting the $\mathrm{pH}$ to 6.95 . The $\mathrm{pH}$ of sample UF-C (6.95) was used as a baseline to investigate the effect of $\mathrm{pH}$ on HCT in all samples.

\section{Statistical Analysis}

The sample treatments and chemical analyses in the present study were run in duplicate. Values were means of replicate determinations and the differences between the means of the treatments were compared by one-way ANOVA at a significance level of $P<0.05$. The statistical analysis was conducted using the GLM command in Minitab (v.16.1, Minitab Inc., State College, PA). Differences between the treatments were tested using Tukey's honestly significant difference (HSD) intervals with $\alpha=0.05$.

\section{RESULTS AND DISCUSSION}

\section{Composition}

Table 1 summarizes the composition of the MPC powders. We observed no significant differences in the ash and moisture contents across the powders $(P$ $>0.05)$. The DF powders showed higher protein and lower lactose contents as a consequence of the diafiltration process $(P<0.05$; Table 1$)$. We found no differences in the compositional parameters with addition of GDL except for the total Ca content and $\mathrm{pH}$ after reconstitution.

As expected, the total Ca concentration was higher in DF powders than in UF powders because of the higher micellar casein content in MPC80 than in MPC65. The difference in the Ca content of control and GDL-treated powders was not significant for UF powders $(P>0.05)$; however, DF-G showed a significant decrease in Ca content compared with DF-C $(P<0.05)$. In addition, DF-G showed the lowest concentration of total Ca.

After reconstitution ( $5 \% \mathrm{wt} / \mathrm{wt})$ in water, GDLtreated powders exhibited significantly lower $\mathrm{pH}$ values compared with their respective controls. Both UF and GDL significantly affected the $\mathrm{pH}$ of the powders after reconstitution (Table 1). Such differences in $\mathrm{pH}$ may play an important role in the processing properties of the powders; for example, in their thermal stability (Sauer and Moraru, 2012). Crowley et al. (2014) demonstrated that at $140^{\circ} \mathrm{C}$, heat stability of MPC suspensions at $\mathrm{pH}<6.8$ decreased with increasing protein content. This was attributed to an increased $\mathrm{Ca}$ ion activity in the suspensions.

\section{Characterization of MPC Powders}

Figure 2 summarizes the effect of concentration and GDL on the cold solubility of the powders. The MPC65 powders were significantly more soluble than the MPC80 powders. It is important to note that this solubility determination method (described earlier), conventionally used in the field, is based on total solids, and comparisons can be made only based on protein concentration. No significant differences in the solubility of UF-G powder were found compared with UF-C; 


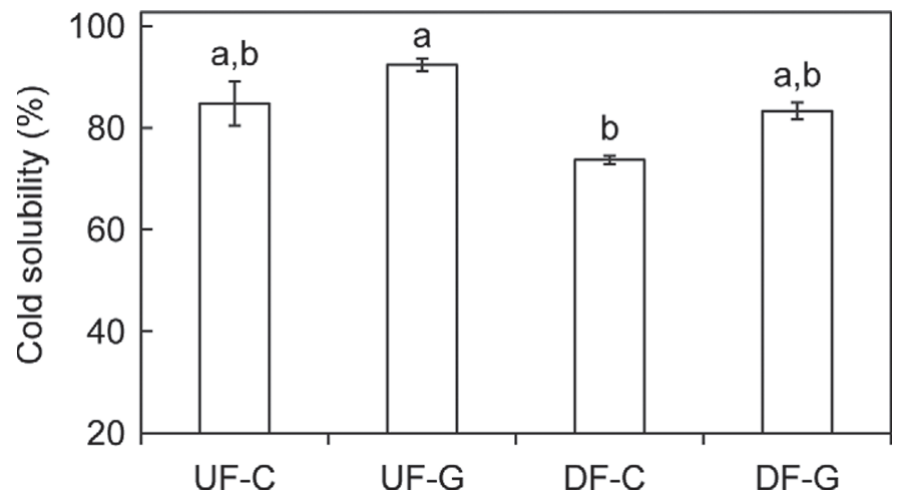

Figure 2. Cold solubility of powders after dispersion at $23^{\circ} \mathrm{C}$ for 3 $\mathrm{h}$ at $5 \%$ solids (wt/wt). UF-C $=\mathrm{UF}$ control; UF-G $=\mathrm{UF}$ and acidified with glucono- $\delta$-lactone (GDL); DF-C = diafiltered control; DF-G = diafiltered and acidified with GDL. Letters indicate significant differences by Tukey's honestly significant difference procedure using $\alpha=$ 0.05. Error bars represent standard deviations.

however, the solubility of DF-G was significantly higher $(P<0.05)$ than that of the corresponding control (DF$\mathrm{C}$; Figure 2). We concluded that dispersion of casein micelles at $23^{\circ} \mathrm{C}$ may be improved by acidification (addition of GDL) before UF in high-protein MPC.

These results were consistent with previous reports demonstrating that MPC is affected by the presence of Ca (Carr, 2002) or serum components at drying (Gaiani et al., 2005). Davenel et al. (1997) proposed that reducing the number of calcium phosphate bridges between the casein micelles, which would normally be produced during the drying of milk products, would improve the solubility of MPC powders. Gaiani et al. (2005) also reported that adding milk ultrafiltrate to native phosphocaseinates before spray-drying favored rapid rehydration. This improvement was attributed to the hygroscopic nature of the components present in the ultrafiltrate. Sikand et al. (2013) also reported that addition of salt $(\mathrm{NaCl}$ or $\mathrm{KCl})$ during the diafiltration stage of MPC80 manufacturing improves solubility of the resulting powder. Mao et al. (2012) indicated that the addition of $\mathrm{NaCl}$ during diafiltration can modify the strength of hydrophobic interactions and disulfide interchange reactions and thereby affect protein aggregation and the solubility of MPC powders.

The low content of serum material in the high-protein DF powders (MPC80) was one of the causes for their inferior dispersability compared with the UF powders (MPC65). The extended loss of serum components during diafiltration allowed for additional proximity of casein micelles and facilitated the casein-casein interactions, during diafiltration and the subsequent drying. McKenna (2000) found that formation of relatively large $(\sim 100 \mu \mathrm{m})$ particles in MPC is attributed to protein-protein interactions resulting from the fusion of casein micelles. It was previously reported that when water is removed and the volume fraction of casein micelles is increased, the decreased distance between the casein micelles may result in the partial collapse of the $\kappa$-casein layer (DeKruif, 1998). As a consequence, the rate of aggregation of casein micelles in a concentrated system would increase because of an increase in the probability of effective collisions (DeKruif, 1998).

The addition of GDL did not affect particle density of any of the powders studied $(P>0.05$; Figure 3$)$. It is important to note that DF increased the particle density of MPC powders significantly $(P<0.05)$ due to the higher protein concentration in the retentate. Particle density influences other physical properties of the powder such as bulk density. It is important that powders have a high bulk density to reduce their volume, especially when they are to be shipped over long distances. A powder with high bulk density requires less packaging material. Other aspects of packaging such as selection of machinery for handling, requirement of packaging materials, and the container volume are also decided based on the density of a powder (BarbosaCanovas and Juliano, 2005).

Figure 4 illustrates the surface morphology of the MPC powders as analyzed by scanning electron microscopy. The UF and DF treatments as well as the addition of GDL before filtration did not seem to affect powder size distribution or granule morphology. Kim et al. (2003) found that shape and morphology of a powder particle depends on the type of raw material, degree of heat treatment, and other compositional and processing parameters. The observations of the current experiment indicate that the changes found in the rehydration of the MPC powders cannot be attributed to modifications of particle shape or surface morphology.

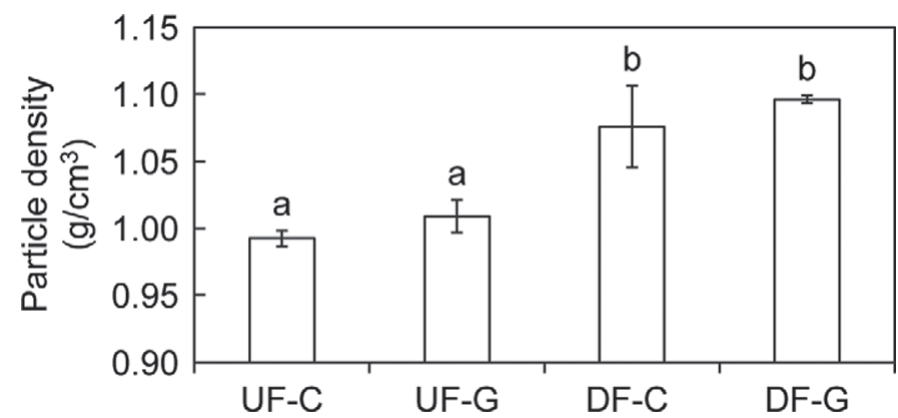

Figure 3. Particle density of powders. UF-C $=$ UF control: UF-G $=\mathrm{UF}$ and acidified with glucono- $\delta$-lactone (GDL); DF-C $=$ diafiltered control; DF-G $=$ diafiltered and acidified with GDL. Letters indicate significant differences by Tukey's honestly significant difference procedure using $\alpha=0.05$. Error bars represent standard deviations. 


\section{Particle Size of Reconstituted MPC Powders}

After cold reconstitution for $3 \mathrm{~h}$ under stirring (see Materials and Methods), the particle size distribution of the powders was analyzed using light scattering, as shown in Figure 5. We detected no statistically significant differences in the particle size distribution of the reconstituted MPC powders. All dispersions showed a monomodal distribution of sizes, with a large peak appearing between 10 and $100 \mu \mathrm{m}$ diameter. These results indicated that although the apparent solubility index of MPC80 powders was high (Figure 2), and with some differences between DF-C and DF-G, rehydration at $23^{\circ} \mathrm{C}$ under stirring for $3 \mathrm{~h}$ was not sufficient to regain the original size distribution of casein micelles. It is important to note that in light scattering, large particles contribute greatly to the signal. The average diameter of casein micelles is about $200 \mathrm{~nm}$ (De Kruif, 1998;
Holt, et al., 2003) and a higher temperature is needed for efficient recovery of the original casein micelles' size and thus for for full rehydration of MPC powders. These results confirm previous reports that high temperature and a high shear of the dispersing liquid are needed for full solubilization of MPC powders (Ferrer et al., 2008; Mimouni et al., 2009).

\section{Thermal Stability of Reconstituted MPC Powders}

Table 2 summarizes the HCT for the dispersions after reconstitution at 5\% solids. Powder UF-C showed high heat stability, with 107 min before any visible signs of coagulation. However, sample DF-C showed a very low heat stability that could not be recovered even after adjustment to the $\mathrm{pH}$ of the UF control (6.9). Regardless of acidification, DF dispersions were less stable compared with UF dispersion upon heating at $120^{\circ} \mathrm{C}$.
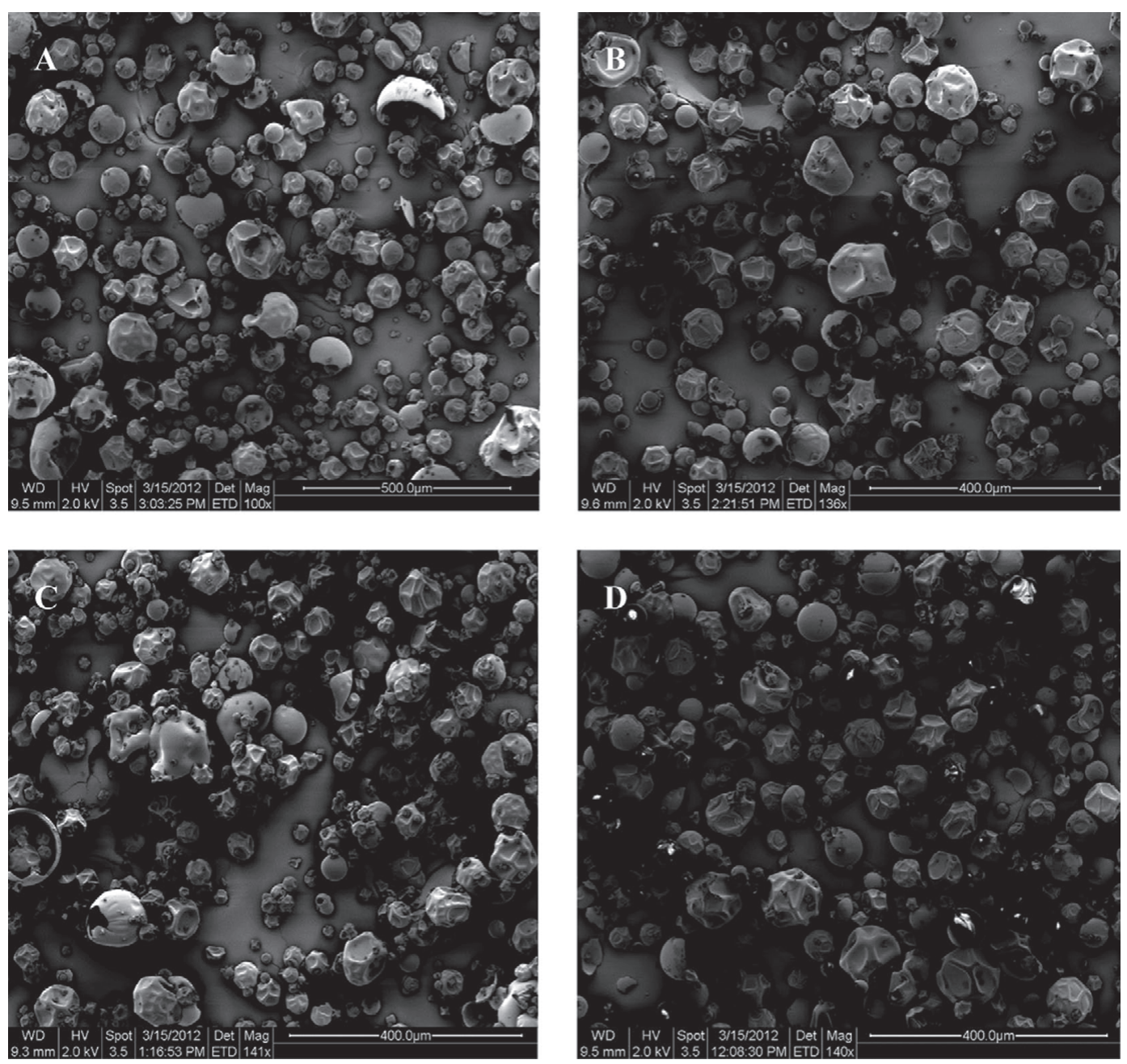

Figure 4. Scanning electron microscopy images of (A; scale bar $=500 \mu \mathrm{m})$ UF control; (B; scale bar $=400 \mu \mathrm{m})$ UF and acidified with glucono- $\delta$-lactone $(\mathrm{GDL}) ;(\mathrm{C}$; scale bar $=400 \mu \mathrm{m})$ diafiltered control; $(\mathrm{D} ;$ scale bar $=400 \mu \mathrm{m})$ diafiltered and acidified with GDL. 


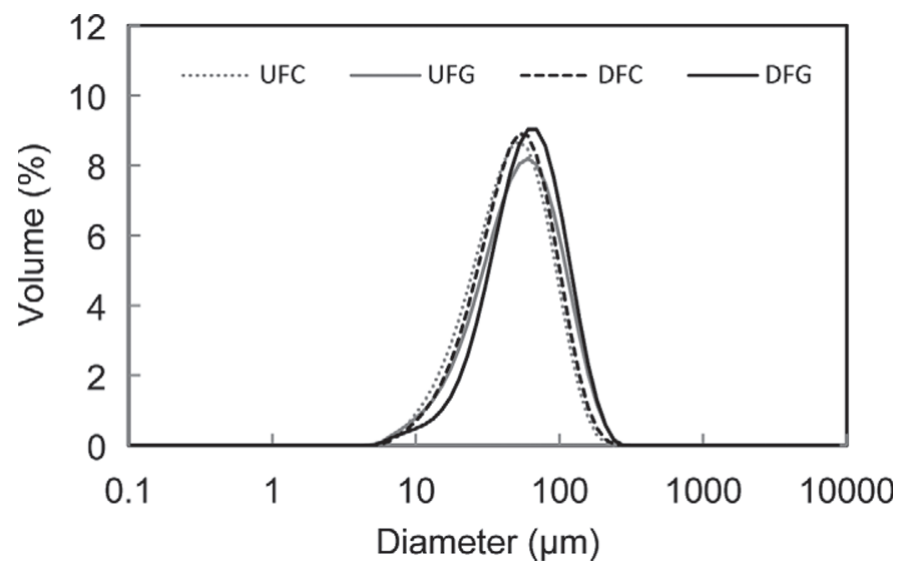

Figure 5. Particle size distribution (\% of volume) of reconstituted $\left(5 \% \mathrm{wt} / \mathrm{wt}\right.$ solids in water at $\left.23^{\circ} \mathrm{C}\right)$ powders. UFC $=\mathrm{UF}$ control; UFG $=\mathrm{UF}$ and acidified with glucono- $\delta$-lactone (GDL); DFC = diafiltered control; DFG = diafiltered and acidified with GDL.

Within treatment, acidification decreased the HCT of both UF and DF samples (Table 2).

When compared at the same $\mathrm{pH}$ value, both GDLtreated samples showed HCT similar to their controls, indicating that $\mathrm{pH}$ is a major factor in imparting heat stability of milk. It is indeed known that a rapid decrease in milk coagulation time occurs with decreasing $\mathrm{pH}$ (Fox and Nash, 1979). The DF treatment also strongly affected the heat stability of milk, suggesting that serum composition has a major effect on heat stability. However, it is important to point out that the differences in Ca content between DF-C and DF-G did not cause a significant difference in the coagulation time.

\section{CONCLUSIONS}

In the present study, we investigated the effect of partial acidification of milk before membrane filtration on the composition, solubility, and thermal stability of the final powder. Although acidification of milk to $\mathrm{pH}$

Table 2. Heat coagulation time (mean $\pm \mathrm{SD} ; \mathrm{n}=3$ ) of reconstituted powders (5\% wt/wt solids) at $120^{\circ} \mathrm{C}$ at original $\mathrm{pH}$ (before) and after adjusting $\mathrm{pH}$ to 6.95 (as a baseline $\mathrm{pH}$ for comparison; after)

\begin{tabular}{lcc}
\hline & \multicolumn{2}{c}{ Heat coagulation time $(\mathrm{min})$} \\
\cline { 2 - 3 } Sample $^{1}$ & Before & After \\
\hline UF-C & $107 \pm 1.0$ & $107 \pm 1.0$ \\
UF-G & $0.5 \pm 0.0$ & $107 \pm 1.0$ \\
DF-C & $2.4 \pm 0.5$ & $2.0 \pm 0.5$ \\
DF-G & $0.2 \pm 0.0$ & $2.0 \pm 0.5$ \\
\hline
\end{tabular}

${ }^{1} \mathrm{UF}-\mathrm{C}=\mathrm{UF}$ control; UF-G $=\mathrm{UF}$ and acidified with glucono- $\delta$-lactone (GDL); DF-C = diafiltered control; DF-G = diafiltered and acidified with GDL.
6 did not significantly affect the proximate composition of the MPC powders resulting from each UF or DF stage, it increased cold solubility compared with controls. This suggested that partial acidification reduced (at least partly) the protein-protein interactions during drying that may contribute to decreased solubility of high-protein MPC powders. This study also clearly demonstrated that solubilization of powders at $23^{\circ} \mathrm{C}$ for $3 \mathrm{~h}$ under stirring does not fully recover the particle size distribution of the casein micelles, regardless of the treatment. Increased protein content of MPC powders had a strong effect on the heat stability of MPC dispersions, and DF dispersions were significantly less stable than UF dispersions. The preacidification of milk to pH 6 also significantly affected the thermal stability of the dispersions. Acidified MPC samples (both UF and DF) exhibited lower thermal stability compared with their controls; however, adjusting the $\mathrm{pH}$ to 6.9 resulted in increased thermal stability within treatments (UF/ $\mathrm{DF}$ ). This effect was more profound in the UF samples. After $\mathrm{pH}$ adjustment, UF-G showed higher thermal stability, reaching values similar to those for the UFC. The results of this work, which was carried out under conditions close to industrial practices, should bring a better understanding of the changes observed during processing of different MPC powders. The possible effect of partial acidification on other processing properties of MPC (e.g., rennet gelation) may also need investigating, as these powders are often used in cheese making. The mechanisms involved at the molecular level that lead to such functional changes are yet to be understood.

\section{ACKNOWLEDGMENTS}

This project was partly funded by the Ontario Dairy Council (Ottawa, ON, Canada) and the Natural Science and Engineering Council of Canada (Ottawa, ON, Canada). Support was also provided by California Dairy Research Foundation (Davis, CA) and Dairy Research Incorporated (Rosemont, IL). Special thanks to Sean Vink (Dairy Products Tech. Center, California Polytechnic State University, San Luis Obispo)for assistance in the powder manufacture.

\section{REFERENCES}

Alexander, M., and D. G. Dalgleish. 2004. Application of transmission diffusing wave spectroscopy to the study of gelation of milk by acidification and rennet. Colloids Surf. B Biointerfaces 38:83-90.

Alexander, M., L. F. Rojas-Ochoa, M. Leser, and P. Schurtenberger. 2002. Structure, dynamics, and optical properties of concentrated milk suspensions: An analogy to hard-sphere liquids. J. Colloid Interface Sci. 253:35-46.

Anema, S. G., D. N. Pinder, R. J. Hunter, and Y. Hemar. 2006. Effects of storage temperature on the solubility of milk protein concentrate. Food Hydrocoll. 20:386-393. 
AOAC International. 1995. Official Methods of Analysis. 16th ed. AOAC International, Gaithersburg, MD.

Baldwin, A. J., and G. N. T. Truong. 2007. Development of insolubility in dehydration of dairy milk powders. Food Bioprod. Process. 85:202-208.

Barbosa-Canovas, G. V., and P. Juliano. 2005. Physical and chemical properties of food powders. Pages $39-71$ in Encapsulated and Powdered Foods. C. Onwulata, ed. Taylor and Francis Group LLC, New York, NY.

Bhaskar, G. V., H. Singh, and N. D. Blazey. 2001. Milk protein products and processes. Dairy Research Institute, assignee. International Patent No. WO01/41578.

Blazey, N. D., R. J. Knights, and C. Wu. 2000. Membrane filtered milk proteins varying in composition and functional attributes. New Zealand Dairy Board, assignee. International Patent No. WO00/51440.

Carr, A. J. 2002. Monovalent salt enhances solubility of milk protein concentrate. New Zealand Dairy Board, assignee. International Patent No. WO02/096208.

Crowley, S. V., M. Megemont, I. Gazi, A. L. Kelly, T. Huppertz, and J. A. O'Mahony. 2014. Heat stability of reconstituted milk protein concentrate powders. Int. Dairy J. 37:104-110.

Davenel, A., P. Schuck, and P. Marchal. 1997. A NMR relaxometry 639 method for determining the reconstitutability and waterholding capacity of protein-rich milk powders. Milchwissenschaft $52: 35-39$.

Davies, D. T., and J. C. D. White. 1960. Determination of heat induced changes in the protein stability and chemical composition of milk. Pages 1677-1685 in Proc. XV Int. Dairy Congr., London, UK. Vol. 3.

DeKruif, C. G. 1998. Supra-aggregates of casein micelles as a prelude to coagulation. J. Dairy Sci. 81:3019-3028.

Ferrer, M. A., A. R. Hill, and M. Corredig. 2008. Rheological properties of rennet gels containing milk protein concentrates. J. Dairy Sci. 91:959-969.

Fox, P. F., and B. M. Nash. 1979. Physico-chemical characteristics of casein micelles in dilute aqueous media. J. Dairy Res. 46:357-363.

Gaiani, C., S. Banon, J. Scher, P. Schuck, and J. Hardy. 2005. Use of a turbidity sensor to characterize micellar casein powder rehydration: Influence of some technological effects. J. Dairy Sci. 88:2700-2706.

GEA Niro. 2006. GEA Niro method A.11.a: Particle density, occluded air and interstitial air (air pycnometer method); updated June 2006. Accessed Sep. 30, 2014. http://www.niro.com/niro/cmsdoc. nsf/WebDoc/webb7ceec8.

Havea, P. 2006. Protein interactions in milk protein concentrate powders. Int. Dairy J. 16:415-422.

Holt, C., D. G. Dalgleish, and R. Jenness. 1981. Inorganics constituents of milk. 2. Calculation of the ion equilibrium in milk diffusate and comparison with experiment. Anal. Biochem. 113:154-163.

Holt, C., C. G. De Kruif, R. Tuinier, and P. A. Timmins. 2003. Substructure of bovine casein micelles by small-angle X-ray and neutron scattering. Colloids Surf. A Physicochem. Eng. Asp. 213:275-284

Kim, E. H. J., X. D. Chen, and D. Pearce. 2003. On the mechanisms of surface formation and the surface compositions of industrial milk powders. Drying Technol. 21:265-278.
Mao, X., P. S. Tong, S. Gualco, and S. Vink. 2012. Effect of $\mathrm{NaCl}$ addition during diafiltration on the solubility, hydrophobicity and disulfide bonds of $80 \%$ milk protein concentrate powder. J. Dairy Sci. 95:3481-3488.

McKenna, A. B. 2000. Effect of processing and storage on the reconstitution properties of whole milk and ultrafiltered skim milk powders. PhD Thesis. Massey University, Palmerston North, New Zealand.

Mimouni, A., H. C. Deeth, A. K. Whittaker, M. J. Gidley, and B. R. Bhandari. 2009. Rehydration process of milk protein concentrate powder monitored by static light scattering. Food Hydrocoll. 23:1958-1965.

Mimouni, A., H. C. Deeth, A. K. Whittaker, M. J. Gidley, and B. R. Bhandari. 2010. Rehydration of high-protein-containing dairy powder: Slow- and fast-dissolving components and storage effects. Dairy Sci. Technol. 90:335-344.

Mistry, V. V., and J. B. Pulgar. 1996. Physical and storage properties of high milk protein powder. Int. Dairy J. 6:195-203.

Mulvihill, D. M., and M. P. Ennis. 2003 Functional milk proteins: Production and utilisation. Pages 1175-1228 in Advanced Dairy Chemistry. Vol. 1: Proteins, part B. P. F. Fox and P. L. H. McSweeney, ed. Kluwer Academic, New York, NY.

Sauer, A., and C. I. Moraru. 2012. Heat stability of micellar casein concentrates as affected by temperature and $\mathrm{pH}$. J. Dairy Sci. 95:6339-6350.

Schokker, E. P., J. S. Church, J. P. Mata, E. P. Gilbert, A. Puvanenthiran, and P. Udabage. 2011. Reconstitution of properties of micellar casein powder: Effects of composition and storage. Int. Dairy J. 21:877-886.

Schuck, P., A. Davenel, F. Mariette, V. Briard, S. Méjean, and M. Piot. 2002. Rehydration of casein powders: Effects of added mineral salts and salt addition methods on water transfer. Int. Dairy J. $12: 51-57$.

Schuck, P., V. Briard, S. Méjean, A. Davenel, M. Piot, and M. H. Famelart. 1999. Dehydration by desorption and by spray-drying of dairy proteins: influence of mineral environment. Drying Technol. 17:1347-1357.

Schuck, P., M. Piat, S. Méjean, Y. Le Graet, J. Fauquant, and G. Brulé. 1994. Déshydratation par atomisation de phosphocaséinate natif obtenu par microfiltration sur membrane [Spray-drying of native phosphocaseinate obtained by membrane microfiltration]. Lait 74:375-388.

Sikand, V., P. S. Tong, S. Roy, L. E. Rodrigues-Saona, and A. Murray. 2011. Solubility of commercial milk protein concentrates and isolates. J. Dairy Sci. 94:6194-6202.

Sikand, V., P. S. Tong, and J. Walker. 2013. Effect of adding salt during the diafiltration step of milk protein concentrate powder manufacture on mineral and soluble protein composition. J. Dairy Sci. Technol. 93:401-413.

US EPA (United States Environmental Protection Agency). 2007. Method 6020A-Inductively coupled plasma mass spectrometry. US Environmental Protection Agency. Revision 1, February 2007. http://www.epa.gov/osw/hazard/testmethods/sw846/ pdfs/6020a.pdf 